\title{
HUKUM PENGGUNAAN ALAT KONTRASEPSI DALAM PRESPEKTIF AGAMA
}

\section{ISLAM}

\author{
Zamzam Mustofa \\ IAIN Ponorogo \\ zamzam@iainponorogo.ac.id
}

\author{
Nafiah \\ IAIN Ponorogo \\ nafiah.280899@gmail.com
}

\section{Dyna Prasetya Septianingrum \\ IAIN Ponorogo \\ dynaningrum1998@gnail.com}

\begin{abstract}
This study examines the legal use of contraceptives in Islam. With the aim of strengthening the position of Islamic law in the use of contraceptives. The process of collecting data is done through a library research, interviews, and the results of interviews that have been analyzed. Contraception is defined as a tool used in preventing pregnancy. There are two types of contraceptives commonly used to regulate, limit and even stop pregnancy, namely traditional methods of contraception such as the azal system, calendar, thermal, and so on. While modern methods of contraception such as hormonal contraception, Pills, Injections, Implantation KB, IUD, condoms and mantab contraception or vasectomy / tubectomy. Based on an analysis of Islamic law the use of contraceptives was disputed by jurists. Regarding the use of contraceptives, the majority of scholars allow as long as the use of contraceptives is not permanent. While contraception is permanent (vasectomy / tubectomy), the majority of scholars forbid it. Thus it is clear that the essence of the KB program's task is to significantly reduce birth rates.
\end{abstract}

Keywords: Contraception, Islamic law, Islamic perspective.

Abstrak: Alat kontrasepsi adalah alat yang sering digunakan oleh sebagian besar masyarakat karena mempuyai manfaat yang besar. Penelitian ini mengkaji penggunaan alat kontrasepsi secara legal dalam Islam. Dengan tujuan memperkuat posisi hukum Islam dalam penggunaan alat kontrasepsi. Proses pengumpulan data dilakukan melalui studi pustaka, wawancara, dan hasil wawancara yang telah dianalisis. Kontrasepsi diartikan sebagai alat yang digunakan untuk mencegah kehamilan. Ada dua jenis alat kontrasepsi yang biasa digunakan untuk mengatur, membatasi bahkan menghentikan kehamilan, yaitu metode kontrasepsi tradisional seperti sistem azal, kalender, termal, dan lain sebagainya. Sedangkan metode kontrasepsi modern seperti kontrasepsi hormonal, Pil, Suntik, Implantasi KB, IUD, kondom dan kontrasepsi mantab atau vasektomi / tubektomi. Berdasarkan analisis hukum Islam penggunaan kontrasepsi diperdebatkan oleh para ahli hukum. Mengenai penggunaan alat kontrasepsi, mayoritas ulama memperbolehkan selamapenggunaan alat kontrasepsi tidak permanen. Meski kontrasepsi bersifat permanen (vasektomi / tubektomi), mayoritas ulama melarangnya. Dengan demikian jelas bahwa inti daritugas program KB adalah menurunkan angka kelahiran secara signifikan.

Kata kunci: Alat kontresepsi, hukum Islam, perspektif Islam. 


\section{PENDAHULUAN}

Akhir-akhir ini banyak cara yang digunakan oleh seseorang untuk mencegah terjadinya kehamilan. Seiring berkembangnya zaman, sudah banyak sekali ditemukan alat modern dengan berbagai efeknya atau sering kita dengar dengan sebutan alat kontrasepsi sebagai hasil penemuan ilmu dan teknologi, yang kini lebih banyak digunakan karena dianggap lebih menjamin ketimbang menggunakan cara tradisional. Kontrasepsi disini adalah cara yang dijadikan obat yang digunakan dalam program $\mathrm{KB}$ untuk mencegah, mengatur, membatasi bahkan mentiadakan terjadinya kelahiran.

Ditengah munculnya banyak kasus terkait dua persoalan tersebut dalam penggunaan alat kontrasepsi tampaknya perlu dikuatkan kembali kedudukan hukum dalam penggunaan alat kontrasepsi yang akhir-akhir ini banyak sekali diminati. Padahal tujuan awal pemerintah mengadakan program $\mathrm{KB}$ iniantara lain hanya untuk mengatur angka kelahiran supaya tidak melahirkan terlalu muda, tidak melahirkan terlalu cepat dan tidak melahirkan terlalu tua, karena kondisi tersebut akan membahayakan nyawa sang ibu. Akan tetapi munculnya program ini malah dijadikan kesempatan bagi masyarakat untuk melakukan hal-hal yang mengarah pada perbuatan dosa besar. Perlu diperhatikan bersama bahwa akhir-akhir ini semakin banyaknya tempat-tempat lokalisasi, semakin maraknya sex bebas dan dengan adanya alat kontrasepsi ini malah menjadikan senjata ampuh bagi mereka untuk melakukan perbuatan dosa karena dengan alat kontrasepsi ini mereka tidak akan khawatir akan terjadinya kehamilan diluar nikah. Adanya alat ini mereka semakin bebas untuk bergonta-ganti pasangan, berhubungan badan dengan selain muhrimnya semakin leluasa untuk memuaskan hasrat nafsu mereka tanpa memperdulikan dosa. Oleh karena itu perlu dikaji lebih dalam lagi bagaimana kedudukan hukum dalam permasalahan-permasalahan yang muncul akhir-akhir ini terkait dengan penggunaan alat kontrasepsi. Sebenarnya ada dua macam alat kontrasepsi yakni alat kontrasepsi tradisional (tidak menggunakan teknologi modern/alamiah) dan alat kontrasepsi modern (pembuatannya menggunakan alat kontrasepsi). Adapun alat kontrasepsi tradisional seperti 'azal, kalender, suhu badan basal (termal), lendirserviks (billings), sympotermal. Sedangkan kontrasepsi modern seperti kontrasepsi hormonal, pil, suntikan, susuk KB, AKDR atau IUD, kondom dan kontrasepsi mantab atau operasi vasektomi/tubektomi juga lebih dikenal dengan cara konsepsional. ${ }^{1}$ Kontrasepsi yang paling banyak digunakan dewasa ini adalah Kontrasepsi hormonal, suntikan, dan kontrasepsi Mantab dengan operasi tubektomi. Kontrasepsi hormonal diperkirakan penggunanya lebih

\footnotetext{
${ }^{1}$ Hanafi Hartanto, “Keluarga Berencana Dan Kontrasepi” (Jakarta: Pustaka Sinar Harapan, 2010), 42.
} 
dari 55 juta wanita didunia, sedang kontrasepsi suntikan lebih dari 10 juta wanita di dunia. Efektivitasnya secara teoritis hampir (99,98-100\%), meskipun belum dapat dikatakan aman $100 \%$. Kontrasepsi suntik yang banyak digunakan dan secara resmi digunakan dalam program keluarga berencana adalah Medroksiprogesteronaseat $150 \mathrm{mg}$ dalam bentuk depo dan noretindronenantat $200 \mathrm{mg}$. Kedua sediaan ini diberikan pada hari ke-5 pendarahan haid secara IM yang dalam di daerah gluteus. ${ }^{2}$.

\section{KAJIAN TEORI}

Menurut Farida penulis jurnal "Penggunaan Alat Kontrasepsi Suntik dan Pil Terhadap Peningkatan Berat Badan Pada Ibu Pasangan Usia Subur" dijelaskan bahwa Kontrasepsi terdiri dari "kontra" artinya mencegah atau melawan serta "konsepsepsi" yaitu bertemunya sel telur dengan sel sperma sehingga terjadi kehamilan. Hal ini juga dijelaskan oleh pakar terkemuka seperti farrer, beliau mengatakan bahwa kontrasepsi adalah mencegah bertemunya sel telur yang matang dengan sel sperma saat melakukan hubungan badan dengan pasangan. Sedangkan menurut Winkjosastro, mengatakan bahwa kontrasepsi adalah upaya mencegah terjadinya kehamilan, alat yang digunakan untuk menunda kehamilan dan menjarangkan jarak kelahiran. Berbeda dengan pendapat Suratun, menurut Suratun kontrasepsi adalah menghindari/mencegah terjadinya kehamilan sebagai akibat dari pertemuan sel telur matang dengan sperma. Sedangkan pakar yang satu ini yakni Nugroho dan Utama, menurutnya pengertian dari kontrasepsi adalah pencegahan terbuahinya sel telur oleh sel sperma (konsepsi) atau pencegahan menempelnya sel telur yang dibuahi dalam dinding rahim wanita. ${ }^{3}$ Dari beberapa penjelasan pakar tersebut penulis menyimpulkan bahwasanya kontrasepsi adalah alat yang dipergunakan sebagai salah satu cara untuk pencegahan terjadinya kehamilan dengan menghalangi pertemuan antara sel sperma denga sel telur sehingga tidak terjadi yang namanya pembuahan dalam rahim.Jenis-Jenis Kontrasepsi, Perlu diketahui bersama bahwasanya banyak sekali macam-macam, metode kontrasepsi, baik kontrasepsi bagi perempuan maupun pria. Dilihat dari segi cara kerjanya, kontrasepsi dibagi menjadi dua macam yakni kontrasepsi tradisional dan kontrasepsi modern.

\footnotetext{
${ }^{2}$ Gemy Nastity Handayany, “Kontrasepsi Dalam Kajian Islam,” Jurnal Al-Firk Volume 17 Nomor 1 Tahun 2013, n.d., 232.

${ }^{3}$ Si Manis, “Alat Kontrasepsi,” Pelajaran.co.id, 2019, https://www.pelajaran.co.id.
} 
1. Kontrasepsi Tradisional

a. 'azal

'azal adalah senggama terputus. Hal ini dilakukan oleh suami dengan tujuan agar sperma jatuh diluar rahim. Cara dilakukan oleh suami atas dasar persetujuan istri sebab istri berhak terhadap kelahiran anak dan kenikmatan bersenggama. Dan kejadian ini sudah diketahui sejak zaman Rasulullah SAW masih hidup. ${ }^{4}$

b. Kalender

Dasarnya dengan menentukan waktu evolusi dari data haid yang dicatat 6-12 bulan terakhir. Tahun 1930 Kyusaku Ogino di Jepang dan di Herman Knaus di Australia, menemukan bahwa:

Ogino: ovulasi biasanya terjadi pada hari ke-15 sebelum haid berikutnya, dapat pula terjadi 12-16 hari sebelum haid datang.

Knaus: Ovulasi selalu terjadi pada hari ke-15sebelum haid yang akan datang. Problem terbesar dengan metode kalender yakni jarang ada wanita yang mempunyai siklus haid teratur setiap 28 hari.

c. Suhu Badan Basal

Dasar dengan peninggian suhu badan basal $0.2-0.5^{\circ} \mathrm{C}$ pada waktu ovulasi. Mulai 1-2 hari setelah ovulasi, dan juga disebabkan karena peninggian hormon progesteron. Efektivitasnya Angka kegagalan: 0.3-6.6 kehamilan pada wanita per tahun.

d. Lendir Serviks

Dimulai dari hari pertama diketahui dengan adanya lendir setelah haid dan berkelanjutan selama dengan hari ke-4 setelah gejala puncak (peak sympotom). Efektivitasnya angka kegagalan:0.4-39.7 kehamilan pada wanita per tahun.

e. Sympto-Termal

Dasar dengan adanya kombinasi antara bermacam metode KB alamiah untuk menentukan masa subur. Efektivitasnya angka kegagalan: 4-9-34.4 kehamilan pada 100 wanita per tahun.Disini dapat disimpulkan bahwasannya kontrasepsi tradisional tidak memberi dampak negatif apapun karena memang dilakukan tanpa memakai alat bantu yang mengandung zat kimia yang akan berakibat buruk terhadap tubuh pemakai.

\section{Kontrasepsi Modern}

${ }^{4}$ Shidiq Sapiudin, "Fikih Kontemporer” (Jakarta: Kencana, 2017), 30. 
a. Kontrasepsi Hormonal

Kontrasepsi ini mengandung esterogen atau progestin atau gabungan dari keduanya. Biasanya kontrasepsi ini banyak tersedia di klinik-klinik. Preparat-preparat ini bervarisasi dan secara kimiawi dan banyak mempunyai kemiripan antara satu sama lain, tetapi juga memiliki perbedaan yang jelas. Adapun dampak negatif yang timbul akibat pemakaian kontrasepsi hormonal yaitu:

1) Mual terjadi pada 50\%-70\% wanita

2) Nyeri tekan pada payudara

3) Pusing

4) Nyeri abdomen

5) Gangguan siklus menstruasi disertai pendarahan abnormal.

b. Suntik

Suntikan termasuk dalam kelompok alat kontrasepsi hormonal. Sesuai dengannamanya, cara pemakaiannya dengan menyuntikkan zat hormonal ke dalam tubuh. Zathormonal yang terkandung dalam cairan suntikan dapat mencegah kehamilan dalam waktu tertentu.Biasanya efektif selama 1-3 bulan, tergantung pada kandungan dan jenis zat yang ada. Adapun dampak negatif yang timbul akibat pemakaian kontrasepsi suntik yaitu:

1) Gangguan haid, ini yang paling sering terjadi

2) Berat badan bertambah

3) Sakit kepala

4) Ada sedikit peninggian dari kadar insulin penurunan HDL-Kolestrol.

c. Alat Kontrasepsi Bawah Kulit (Implan)

Implan, oleh orang awam biasa dikenal dengan susuk KB. Menurut BKKBN 2006,implan terdiri dari 1 batang, 2 batang, dan 6 batang. Implan ini dimasukkan dibawahkulit pada lengan bagian atas.Sangat efektif untuk masa 3 tahun (untuk jenis 1 dan 2batang) dan 5 tahun (untuk jenis 6 batang). Menurut Yayasan Permata Hati Kita(2003), alat KB yang ditempatkan di bawah kulit ini efektif mencegah kehamilandengan cara mengalirkan secara perlahan-lahan hormon yang dibawanya. Selanjutnyahormon akan mengalir ke dalam tubuh lewat pembuluh-pembuluh darah. Adapun dampak negatif yang timbul akibat pemakaian kontrasepsi implan yaitu: 
1) Perubahan pola haid yang terjadi kira-kira $60 \%$ akseptor dalam tahun pertama

2) Pendarahan bercak

3) Berkurang panjangnya siklus haid

4) Amenore

5) Bertambahnya hari-hari pendarahan dalam 1 siklus.

d. Alat Kontrasepsi dalam Rahim (IUD)

IUD (Intra Uterine Device), atau dalam bahasa Indonesia disebut alat kontrasepsidalam rahim (AKDR) adalah alat kontrasepsi yang oleh masyarakat awam biasadisebut spiral. Sesuai dengan namanya AKDR, alat ini dipakai di dalam rahim.Sejakmetode AKDR dikenalkan banyak orang menggunakan untuk program pengaturanjumlah anak dalam keluarga karena relatif aman. Adapun dampak negatif yang timbul akibat pemakaian kontrasepsi IUD yaitu:

1) Biaya lebih mahal

2) Harus diganti setelah pemakaian 18 bulan

3) Lebih sering menimbulkan pendarahan mid-siklus dan pendarahan bercak

4) Rasa sakit/nyeri dikemudian hari

5) Muntah, keringat dingin dan syncope.

e. Pil

Pil KB adalah suatu tablet berisi hormon estrogen atau progestin yang diminum olehwanita secara teratur untuk mencegah kehamilan. ${ }^{5}$ Cara kerja pil ini adalah mencegahproses pematangan telur sehingga tidak bisa dibuahi. Adapun dampak negatif yang timbul akibat pemakaian kontrasepsi Pil KB yaitu:

1) Kurang efektif mencegah kehamilan

2) Menambah insidens dari pendarahan bercak karena pil tidak mengandung estrogen

3) Lupa minum 1 atau 2 tablet oleh sebab muntah atau diare.

${ }^{5}$ Erna Sulistio and Dwi Ispriyanti, "Penerapan Regresi Logistik Multinomial Pada Pemilihan Alat Kontrasepsi Wanita (Studi Kasus Di Desa Tonggara Kecamatan Kedungbanteng Kabupaten Tegal)," Media Statistika 3, no. 1 (2010): 32. 


\section{f. Sterilisasi (Vasektomi/Tobektomi)}

Yaitu operasi pemutusan atau pengikatan saluran/pembuluh yang menghubungkan testis (pabrik sperma) dengan kelenjar prostat (gudang sperma menjelang diejakulasi) bagi laki-laki. Atau tubektomi dengan operasi ke dalam rongga rahim, sementara sperma laki-laki yang masuk ke dalam vagina wanita tidak mengandung spermatozoa sehingga tidak akan terjadi kehamilan walaupun koitus tetap normal tanpa gangguan sperma. Akibat dari sterilisasi ini akan menjadi mandul selamanya. ${ }^{6}$ Adapun dampak negatif yang timbul akibat pemakaian kontrasepsi tubektomi yaitu:

1) Resiko komplikasi, karena kesalahan atau kegagalan teknis.

2) Pendarahan yang mungkin terjadi dapat lebih banyak.

3) Saat melahirkan bakteri dapat masuk kedalam rongga pelvis.

Sedangkan adapun dampak negatif yang timbul akibat pemakaian kontrasepsi vasektomi yaitu:

1) Diperlukan suatu tindakan operatif

2) Terkadang menyebabkan komplikasi seperti pendarahan atau infeksi

3) Kontap pria belum memberikan perlindungan total sampai semua spermatozoa

4) Problem psikologis yang berhubungan dengan perilaku seksual yang bertambah parah.

\section{g. Kondom}

Kondom atau jaswadi adalah alat kontrasepsi untuk mencegah kehamilan atau penularan penyakit kelamin pada saat berhubungan badan. Dan biasa dibuat dari bahan karet latex dan dipakaikan pada alat kelamin pria atau wanita pada keadaan ereksi sebelum bersenggama atau bersetubuh. Kondom tidak hanya dipakai oleh pria saja melainkan juga dipakai oleh wanita. Kondom yang diperuntukkan wanita biasanya berbentuk silinder yang kemudian dimasukkan kedalam kemaluan wanita. Sedangkan kondom untuk pria seperti halnya kondom wanita yakni dipasangkan ke alat kelamin wanita. Keduanya memiliki fungsi yang sama yakni mencegah sperma masuk kedalam rahim wanita. ${ }^{7}$

\footnotetext{
${ }^{6}$ Ajat Sudrajat, "Fikih Aktual Membahas Problematika Hukum Islam Kontemporer" (Ponorogo: STAIN Ponorogo Press, 2008), 36.

${ }^{7}$ Joseagush, “Kondom,” WIKIPEDIA, 2019, https://id.m.wikipedia.org.
} 
Dari uraian macam-macam alat kontrasepsi tersebut sudah dapat digambarkan bahwasanya kontrasepsi tradisional tidak memberikan dampak negatif bagi tubuh sehingga lebih aman digunakan sedangkan alat kontrasepsi modern, hampir semua alat kontrasepsi modern mengandung dampak negatif yang lama kelamaan akan membahayakan tubuh pemakainya. Kemudian terkait pembahasan hukum penggunaan alat kontrasepsi dalam prespektif Agama Islam yakni:

1. Kontrasepsi Tradisional

a. 'Azl

Dalam usaha menunda kelahiran anak, bisa dengan 'azl (mengeluarkan sperma di luar vagina). Hukum pemakaian kontrasepsi berupa 'azl yaitu boleh tidak menyebabkan kemandulan secara permanen. Ada sebuah hadits shahih yang membolehkan hukum 'azl, riwayat Muslim dari Jabir:
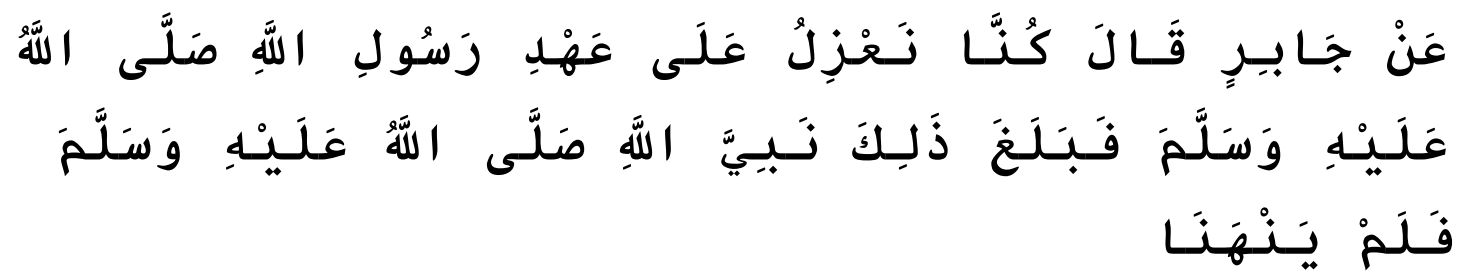

Artinya: Dari Jabir, ia berkata: Kami melakukan 'azl pada masa Rasulullah saw kemudian hal itu sampai kepada Nabi saw tetapi beliau tidak melarang kami.

Ada juga hadis yang melarang 'azl yaitu hadits riwayat Ibnu Majah no. 2003:

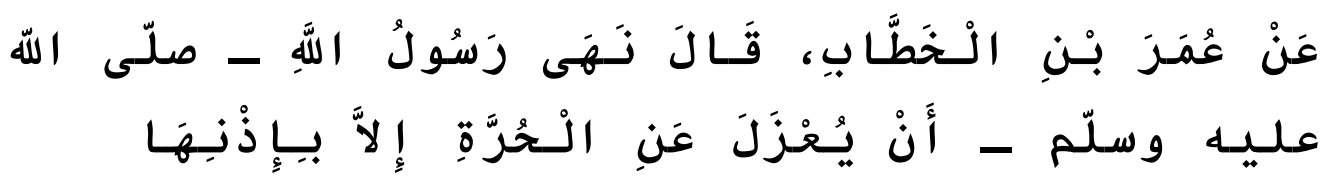

Artinya: Dari Umar bin Khattab, dia berkata bahwa Rasulullah SAW melarang melakukan 'azl terhadap wanita merdeka kecuali atas izinnya.

Dalam menjelaskan kedua hadits tersebut Imam Nawawi dalam Syarah Shahih Muslim menjelaskan bahwa larangan itu bersifat makruh tanzih (makruh yang cenderung kepada hukum boleh), bukan haram: ${ }^{8}$

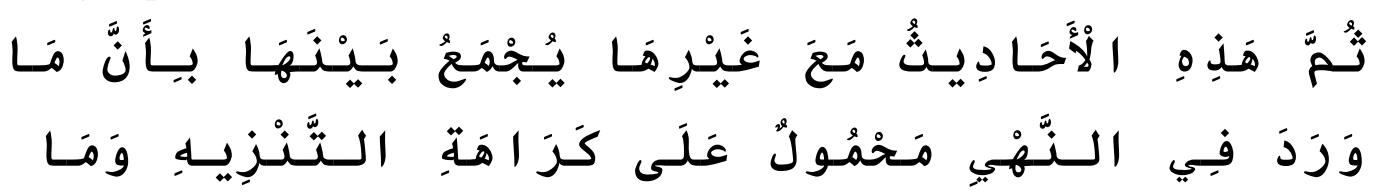

${ }^{8}$ Imam An Nawawi, “Al Minhaj Syarah Shahih Muslim Juz 10,” in Al Minhaj Syarah Shahih Muslim (Beirut: Daru Ihyait Turats, 1329), 9. 


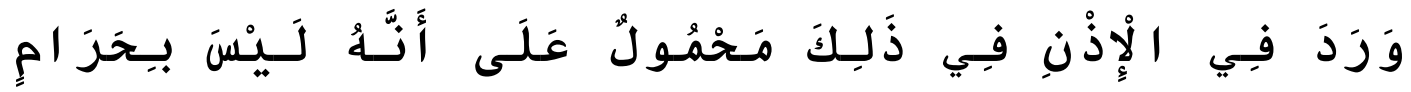

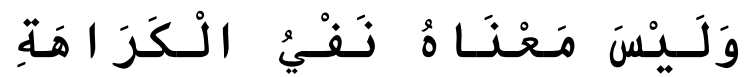

Artinya: Hadits-hadits ini dan yang lainnya digabung dengan maksud bahwa sesungguhnya inti hadits yang melarang 'azl itu diarahkan ke hukum makruh tanzih. Sedangkan hadits yang membolehkan 'azl itu diarahkan bahwa sesungguhnya hukum 'azl tidaklah haram. Dan pemahamannya tidak menjadikan hilangnya hukum makruh 'azl.

Jadi karena hukum makruh tanzih inilah sebaiknya tidak perlu melakukan 'azl ketika ingin memiliki anak karena mengeluarkan sperma di dalam vagina akan memberi kenikmatan lebih bagi suami istri sehingga terciptalah kepuasan dan menjadi keluarga yang sakinah, mawaddah wa rahmah.

b. Kalender

Tidak ada satupun hadis yang melarang kontrasepsi dengan melihat kalender oleh karena itu hukumnya adalah boleh. Sesuai kaidah fiqih:

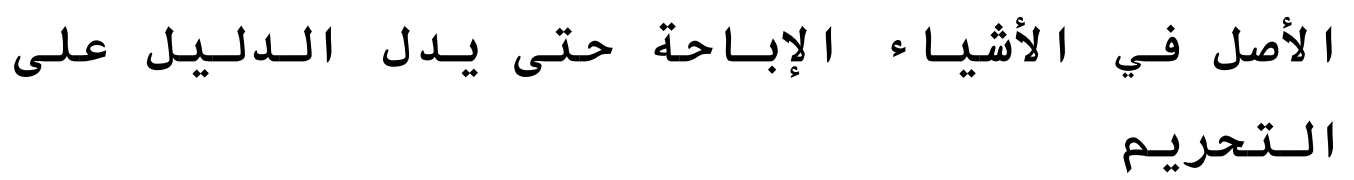

Artinya: Hukum asal segala sesuatu adalah boleh sampai ada dalil yang mengharamkan.

c. Suhu Badan Basal

Kontrasepsi ini hukumnya boleh karena tidak menyebabkan kemandulan permanen sama sekali. Dengan terciptanya keluarga yang ideal maka akan dapat memenuhi hadits nabi yang menyarankan agar tidak membuat anak menjadi miskin: (Ahmad bin Ali bin Hajar Al Asqalany, 1958: 363)

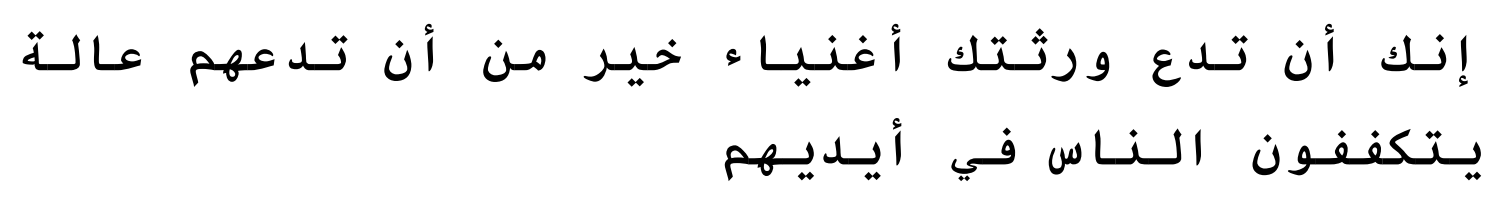

Artinya: Sesungguhnya apabila kamu meninggalkan ahli warismu dalam keadaan kaya adalah lebih baik daripada kamu meninggalkan mereka dalam keadaan.

d. Lendir Serviks 
Pemerintah perlu mendukung upaya ini karena dengan melakukan kontrasepsi ini akan menjaga stabilitas Negara dalam hal populasi penduduk yang ideal sebagaimana kaidah fiqih:

\section{تصرف الإمـام مـنـوط بــالـمصلـحة}

Artinya: Kebijakan pemerintah itu tergantung demi kebaikan.

e. Sympto-Termal

Hukum penggunaan kontrasepsi ini menurut perspetif islam adalah boleh. Ini adalah hal baik yang perlu diterapkan umat islam walaupun mungkin berasal dari pemikiran non muslim. Semua hal baik entah dari muslim ataupun non muslim tetaplah berhak dipakai orang islam karena orang islam adalah yang paling berhak mendapat hal-hal baik. Teknik kontrasepsi ini juga perlu dilakukan untuk mengatur jumlah anak sesuai kondisi. Kebaikan berupa punya banyak anak dikalahkan dengan lebih pentingnya mencegah keburukan punya terlalu banyak anak sebagaimana kaidah fiqih

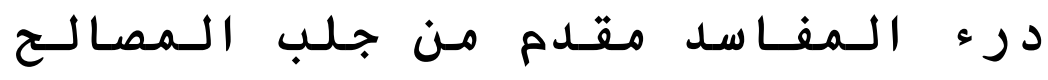

Artinya: Mencegah kerusakan lebih diutamakan daripada mengambil keuntungan.

2. Kontrasepsi Modern

a. Kontrasepsi Hormonal

Syekh Zakaria Al Anshari membolehkan seseorang memakai obat untuk menunda kehamilan selama tidak meyebabkan mandul permanen: ${ }^{9}$

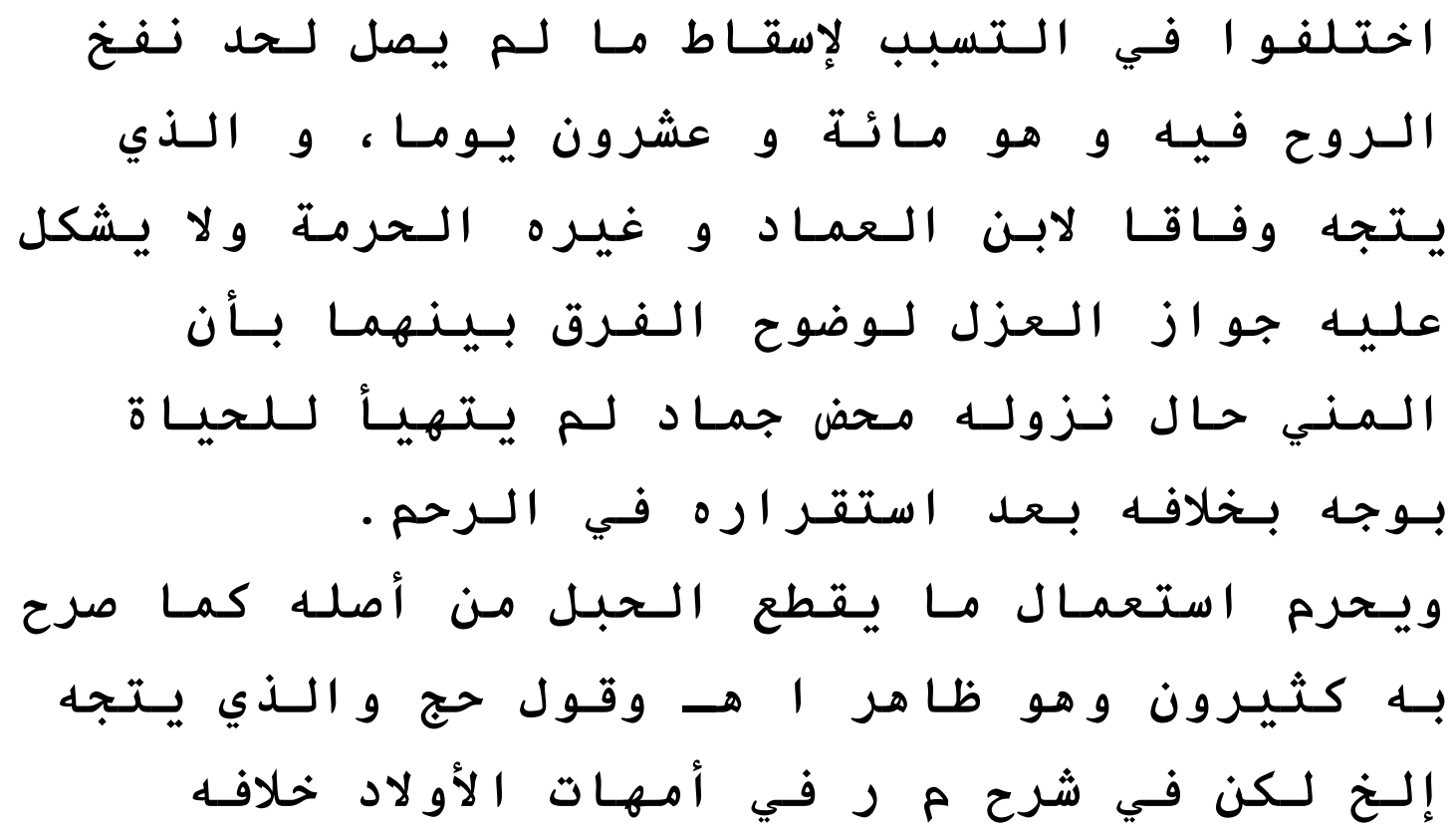

9Zakaria bin muhammad bin Ahmad bin Zakaria Al-Anshari, "Hasyiyatul Jamal 'alal Minhaj Juz 7," in Hasyiyatul Jamal 'alal Minhaj (Beirut: Darul Kutub 'Ilmiyyah, 2013), 221. 


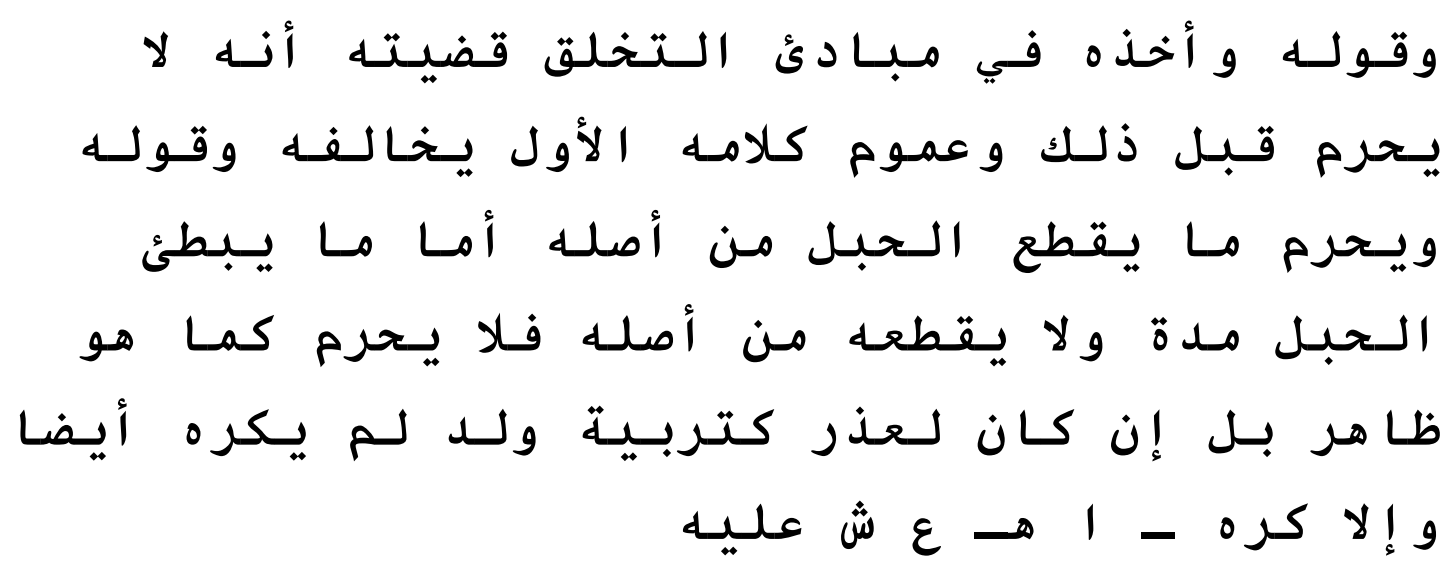

Artinya: Ulama' berbeda pendapat dalam penyebab gugurnya kandungan yang belum sampai ditiupnya ruh ke dalamnya yaitu 140 hari. Golongan ulama' yang cenderung sepakat kepada Imam Ibnu Imad dan selainnya memilih hukum haram. Dan tidak dipermasalahkan pada beliau tentang bolehnya 'azl karena sudah jelasnya perbedaan antara keduanya bahwa sesungguhnya sperma ketika keluar hanyalah benda cair tanpa nyawa berbeda dengan sperma yang sudah dimasukkan ke rahim wanita. Haram penggunaan perkara yang memutus kehamilan sejak dari asalnya sebagaimana yang sudah dijelaskan banyak ulama'. Itu adalah hal yang jelas. Pendapat Ibnu Hajar Al Haitami dan ulama' lain yang cenderung memilih hukum tadi, sedangkan dalam penjelasan Imam Ramli dalam pembahasan "ummahatul aulad" memilih hukum sebaliknya. Pendapatnya pada lafadz "permulaannya penciptaan anak" adalah batasan bahwa sesungguhnya tidak haram melakukan 'azl sebelum itu (penciptaan anak). Adapun maksud dari lafadz "haram sesuatu yang memutus kehamilan dari asalnya" yaitu apabila penggunaan sesuatu untuk menunda kehamilan dalam sementara dan tidak memutus kemampuan hamil sejak dari asalnya maka tidak haram sebagaimana zhahirnya, tetapi bila penundaan kehamilan karena alasan seperti untuk mendidik anak maka tidak makruh hukumnya. Jika tidak begitu maka hukumnya makruh.

b. Suntik

Penggunaan kontrasepsi suntik termasuk kontrasepsi yang bagus karena tetap bisa hubungan intim dengan tenang tanpa khawatir hamil sebab efektivitasnya yang bagus, minim resiko, murah dan cepat. Apabila suami istri dalam keadaan darurat yang tidak dapat dihindari, misalnya untuk menghindari penurunan penyakit dari kedua orang tuanya terutama ibu terhadap anak yang bakal dilahirkan atau terancamnya jiwa si ibu 
yang akan mengandung atau melahirkan bayi. Maka hukumnya boleh sesuai dengan kaidah hukum Islam yang menyatakan: ${ }^{10}$

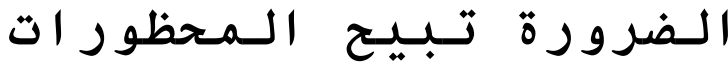

Artinya: Keadaan yang darurat (genting) membolehkan hal-hal yang terlarang.

c. Alat Kontrasepsi Bawah Kulit (Implan)

Alat kontrasepsi ini harus dipasang oleh ahlinya agar tidak timbul luka, yang boleh memasangkan pun adalah dokter wanita karena lengan atas wanita termasuk aurat bagi lelaki bukan mahram sebagaimana pendapat ulama' berikut:

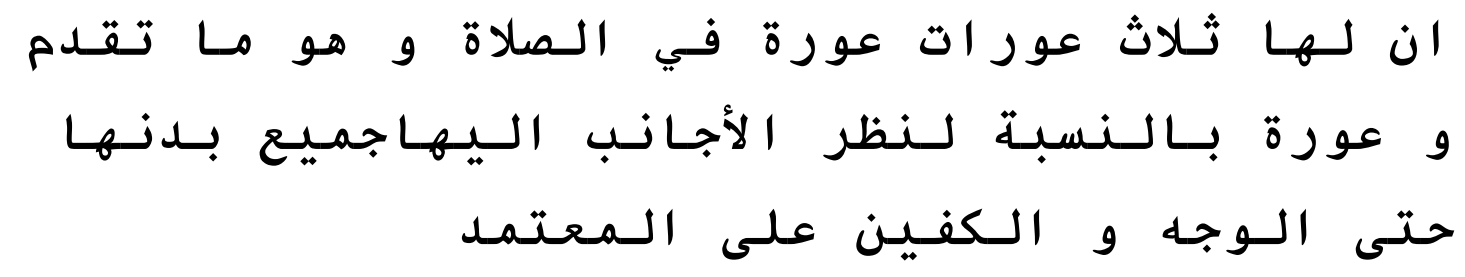

Artinya: "Bahwa perempuan memiliki tiga aurat. Pertama, aurat dalam shalat dan aurat dalam shalat telah dijelaskan. Kedua, aurat yang terkait dengan pandangan pria lain kepadanya, yaitu seluruh badannya termasuk wajah dan kedua telapak tangannya menurut pendapat yang mu'tamad'.

d. Alat kontrasepsi dalam Rahim (IUD)

Kontrasepsi jenis ini boleh dilakukan karena tidak menyebabkan kemandulan permanen. Kontrasepsi ini boleh dilakukan oleh dokter perempuan akan tetapi akan lebih baik apabila yang memasangkan kontrasepsi ini ke istri adalah suaminya sebab suami juga boleh melihat vagina istri sepuasnya. Berikut pandangan ulama' tentang kebolehan suami melihat dan menyentuh vagina istri guna memasang kontrasepsi: ${ }^{11}$ IbnuQudamah, 1997:79

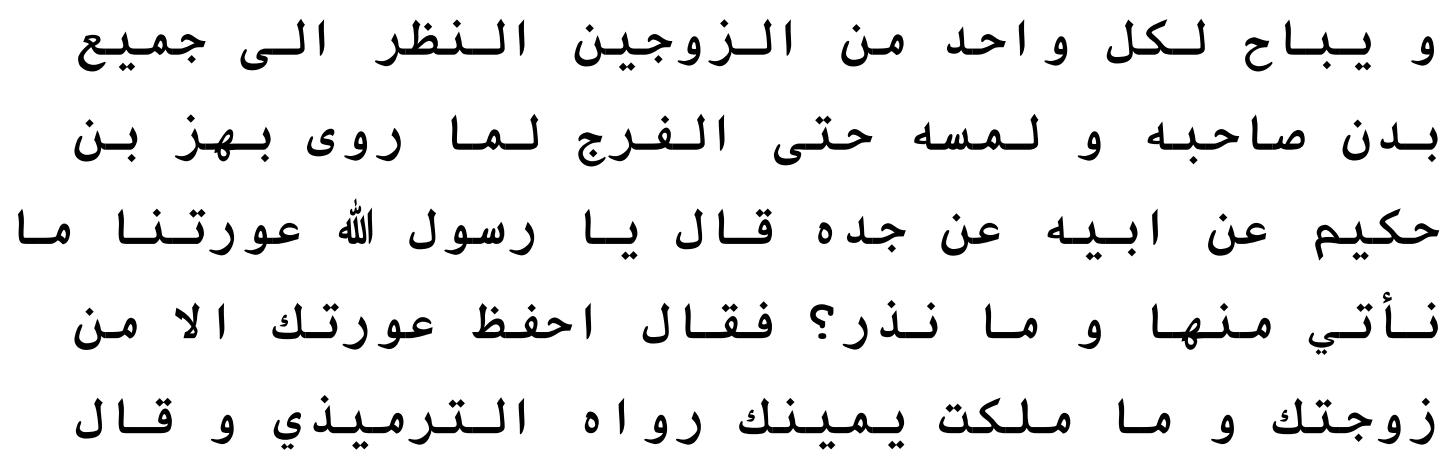

${ }^{10}$ Nazar Sidi Bakry, "Fikih Dan Ushul Fikih," Jakarta: PT. Raja Grafindo Persada, 2003, 131.

${ }^{11}$ Ibnu Qudamah, “Al Mughni Juz 15," in Al Mughni (Riyadh: Daru Alimil Kutub, 1997), 79. 


\section{حـديـث حسن ولأن الـفـرج يـحل لـه الإستمـــاع بـه فـجـاز

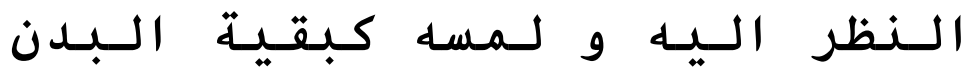

Artinya: Diperbolehkan bagi pasangan suami-istri melihat dan menyentuh semua bagian tubuh pasangannya, termasuk alat vitalnya. Pendapat ini didasarkan pada riwayat Bahaz bin Hakim, bahwa kakeknya bertanya kepada Rasulullah: Wahai Rasulullah saw mana aurat yang boleh kami buka dan mesti kami tutup? Rasul menjawab: Tutup auratmu kecuali untuk istrimu dan budakmu. Diriwayatkan Tirmidzi, status kekuatan hadits ini adalah hasan. Mengapa diperbolehkan? Karena alat vital adalah tempat istimta' (bersenang-senang) dan diperbolehkan melihat dan menyentuhnya, seperti anggota tubuh lainnya.

e. Pil

Penggunaan obat pil ini sebagai kontrasepsi hukumnya boleh karena tidak menyebabkan kehamilan yang permanen. Yang membuat hukum mengkonsumsi obat menjadi haram adalah apabila menyebabkan kemandulan permanen. Sebagaimana disebutkan dalam Kitab Qalyubi: ${ }^{12}$

\section{و يـحرم قـطع الـنـسل ولـو بـدو اء}

Artinya: Dan diharamkan memutuskan kelahiran meskipun dengan obat.

f. Sterilisasi (Tubektomi/Vasektomi)

Vasektomi dan tubektomi hukumnya haram karena membuat mandul secara permanen. Berikut adalah pandangan ulama' tentang keharaman membuat mandul secara permanen: ${ }^{13}$

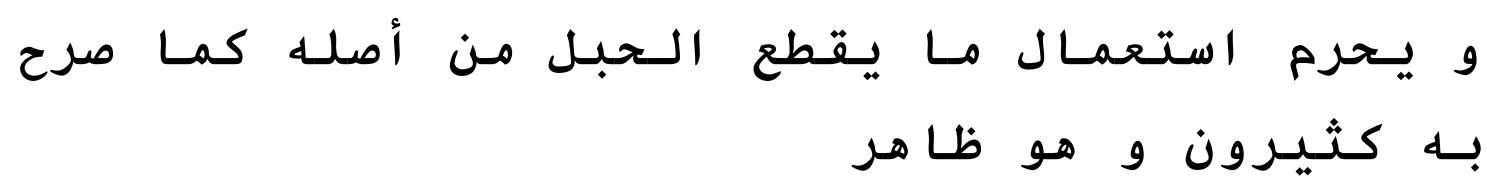

Artinya: Dan diharamkan memakai sesuatu yang dapat memutuskan kehamilan dari asalnya (secara permanen) sebagaimana yang telah banyak ulama paparkan. Hal ini sudah jelas.

g. Kondom

\footnotetext{
${ }^{12}$ Ahmad bin Ahmad bin Salamah Al Umairah, "Hasyiyatani Qalyubi Wa Umairah Juz 4," in Hasyiyatani Qalyubi Wa Umairah (Beirut: Darul Kutub Ilmiyyah, 2015), 576.

${ }^{13} \mathrm{Abu}$ Bakar Ustman bin Muhammad Syatha, "I'anatut Thalibin Juz 4," in I'anatut Thalibin (Beirut: Darul Fikr, 2019), 147.
} 
Pemakaian kondom sebagai kontrasepsi diqiyaskan terhadap 'azl karena punya 'illat berupa sama-sama tidak mengeluarkan sperma di dalam vagina. Hukum kontrasepsi jenis ini juga boleh karena sama sekali tidak membahayakan kemampuan hamil/menghamili. Berikut tambahan pandangan Syekh Wahbah al-Zuhaili tentang qiyas: ${ }^{14}$

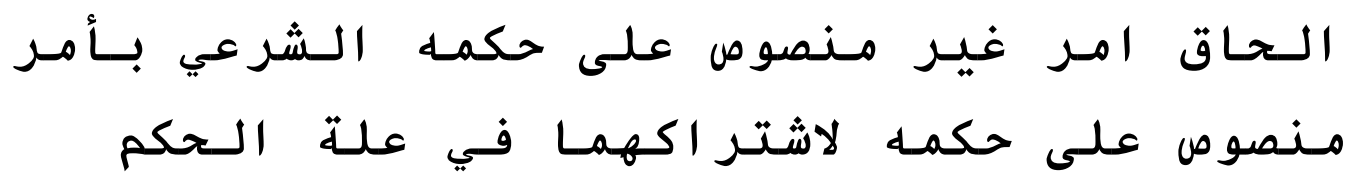

Artinya: Menyamakan sesuatu yang tidak disebutkan hukumnya dalam nas dengan sesuatu yang disebutkan hukumnya oleh nas, disebabkan kesatuan 'illah hukum antara keduanya.

Karena kondom diqiyaskan terhadap 'azl maka hukumnya boleh karena 'azl pun hukumnya boleh. Berikut adalah tambahan dasar tentang kebolehan 'azl: ${ }^{15}$ (Ahmad bin Ali bin Hajar Al Asqalani, 1958: 381)

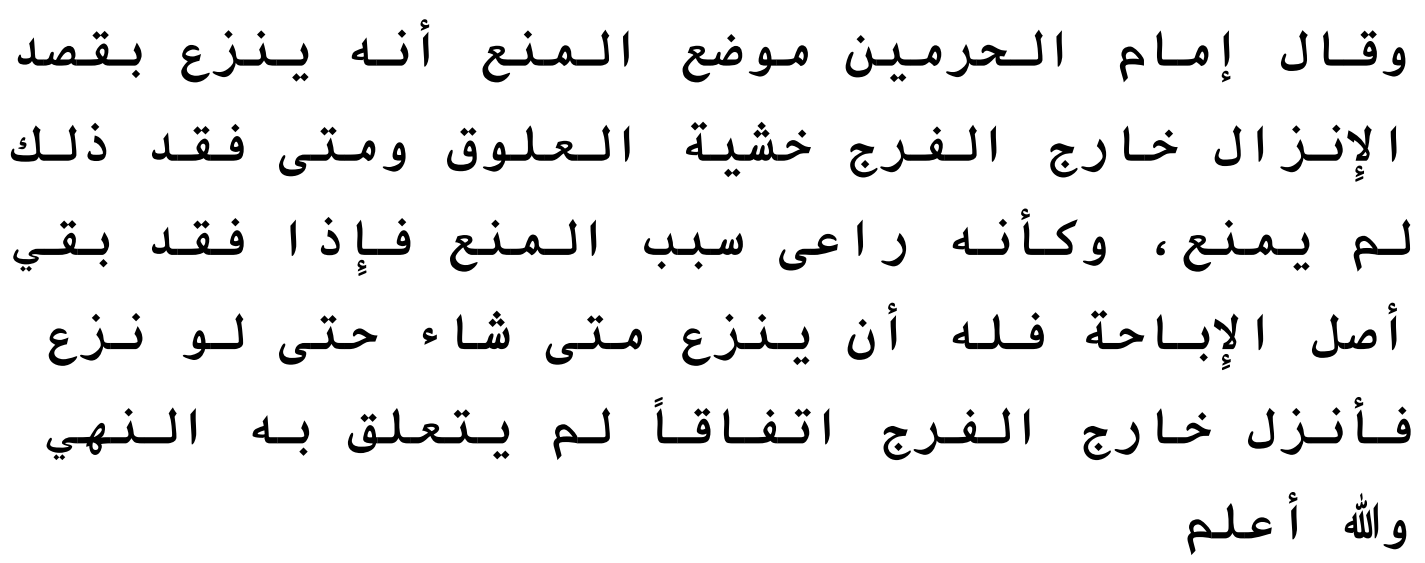

Artinya: Imam Haramain telah berkata, alasan larangan ('azl) yaitu bahwa sesungguhnya apabila seseorang menarik (penis dari vagina) dengan tujuan mengeluarkan (sperma) di luar vagina karena takut (akan mengalami) bencana, jadi ketika tujuan itu hilang maka tidak dilarang (melakukan 'azl). Beliau seperti berhatihati terhadap sebabnya larangan ('azl), sehingga ketika sebab itu hilang maka berlakulah hukum asal yaitu mubah. Maka ia boleh menarik (penisnya) kapanpun ia mau bahkan hingga menarik dan mengeluarkan sperma di luar vagina secara mutlak tanpa terkena larangan Nabi. Wallahu a'lam.

${ }^{14}$ Wahbah Zuhaili, "Ushul Al-Fiqh Al-Islami,” Beirut: Dâr Al-Fikr, 1986, 601.

${ }^{15}$ Ahmad bin Ali bi Hajar Al Asqalani, "Fathul Bari Juz 9," in Fathul Bari (Beirut: Darul Ma'rifat, 1958$), 381$. 


\section{METODE}

\section{Jenis Penelitian}

Study ini menggunakan jenis penelitian Library Research yang mana proses pengumpulan data dilakukan dan diperoleh melalui kajian Kepustakaan, eksplorasi terhadap sejumlah data baik data primer maupun sekunder peneliti membaca atau menelaah serta melakukan identifikasi wacana dari buku-buku kontrasepsi, fiqh kontemporer, kitab fiqh, jurnal, artikel, maupun laporan hasil penelitian terdahulu yang relevan dengan penelitian peneliti serta berkaitan dengan hukum penggunaan alat kontrasepsi dalam prespektif Agama Islam. Adapun buku-buku atau kitab yang relevan dengan penelitian peneliti serta berhubungan dengan alat kontrasepsi dan hukumnya yaitu buku Keluarga Berencana, Fikih Aktual Membahas Problematika Hukum Islam Kontemporer, Hasyiyatul Jamal 'alal Minhaj Juz 7, I'anatut Thalibin Juz 4, dan masih banyak lagi. Selain itu untuk memperkokoh penelitian ini peneliti juga melakukan tehnik wawancara akan hal ini, yakni wawancara dengan narasumbernya tokoh ulama terkemuka di kota Ponorogo yakni Bapak Sunartip, M.SY. yang mana beliau merupakan pengasuh di salah satu Pesantren Mahasiswa AlMutawakkil yang terletak di daerah Ponorogo, beliau juga sekalgus termasuk salah satu dosen ternama di kampus IAIN Ponorogo.

\section{Metode Pengumpulan Data}

Karena peneliti menggunakan jenis penelitian Library Research oleh karena itu metode pengumpulan datanya dengan mengumpulkan buku-buku, kitab-kitab, artikel, jurnal dan karya tulis lainnya yang didalamnya mengungkap dan mengkaji tentang alat kontrasepsi. Selain itu karena peneliti juga melakukan teknik wawancara maka peneliti menggali suatu informasi yang dibutuhkan dari narasumber (Bapak Sunartip M.SY), dan secara langsung narasumber akan memberikan informasi yang sesuai. Selanjutnya dilakukan analisis secara deduktif dan induktif. Maksudnya metode deduktif disini digunakan untuk memperoleh gambaran tentang hukum penggunaan alat kontrasepsi dalam prespektif Agama Islam secara detail, sedangkan metode induktif disini digunakan peneliti agar dapat memperoleh dan mengungkapkan gambaran mengenai hukum penggunaan alat kontrasepsi dalam prespektif Agama Islam.

\section{Metode Analisis Data}

Dalam proses penelitian, ada beberapa langkah yang harus dilakukan oleh peneliti dengan teknik pengumulan data yang didapat harus sesuai. Pertama peneliti menganalisis 
serta mengolah data yang telah didapatkan selama penelitian baik dari data primer maupun sekunder kemudian peneliti menarik kesimpulan data tersebut. Setelah data macam-macam alat kontrasepsi terkumpul, kemudian dianalisis dengan metode deskriptif analilytic. Maksud dari deskriptif adalah metode yang menggunakan pencarian fakta yang diinterpretasi dengan tepat dan analisis yakni menguraikan sesuatu dengan cermat serta terarah. Kedua peneliti juga harus menggali data dan informasi terkait hukum penggunaan alat kontrasepsi dalam prespektif Agama Islam dengan mewawancarai narasumber yang dipilih (Bapak Sunartip M.SY). Yang akhirnya nanti semua data yang telah diperoleh dan dianalisis dapat disusun dan dipaparkan dalam sebuah laporan penelitian tetang hukum penggunaan alat kontrasepsi dalam prespektif Agama Islam.

\section{HASIL}

Dari penelitian yang telah dilakukan memuat hasil dan juga data pendukungnya. Bahwasannya ada dua hal yang harus kita ketahui perbedaannya, kontrasepsi dalam bahasa arab memiliki dua makna yaitu tahdidun nasli dan tandzimun nasli. Tahdidun nasli berarti membatasi keturunan atau membatasi kehamilan yang mana disini hukumnya diharamkan, sedangkan tandzimun nasli artinya menunda keturunan atau menunda kehamilan dan keberadaan hukumnya diperbolehkan. Membatasi kehamilan berarti mencegah untuk selamalamanya tidak memiliki keturunan (permanen) atau sering dikenal dengan sebutan operasi vasektomi/tobektomi dan hal ini hukumnya sangat diperjelas yakni diharamkan oleh semua ulama begitupun haram menurut Sunnah Nabi karena di anggap mendahului kehendak/takdir Allah SWT. Baik membatasi kehamilan dengan cara mensterilisasi rahim, pengangkatan rahim, pemotongan saluran sperma agar tidak membuahi sel telur dan sebagainya yang bersifat pemandulan permanen tanpa sebuah alasan yang dapat dibenarkan oleh syariat. Karena dengan keadaan begini manusia akan lebih mudah terjebak dalam perangkap setan dan dapat terjerumus kedalam dosa besar seperti terjebak kedalam zina. Selain menambah hasrat nafsu pria dan wanita pemandulan juga dapat menimbulkan rasa aman dalam diri manusia dari kehamilan sehingga mereka merasa bebas untuk melakukan seks dengan wanita atau pria lain yang jelas-jelas bukan muhrimnya. Kecuali pada keadaan dimana wanita dalam keadaan dzorurot atau adanya udzur syar'i yang mewajibkan wanita tersebut harus mengangkat rahimnya (operasi tobektomi) karena di khawatirkan jika tidak dilakukan hal tersebut akan membahayakan nyawanya seperti adanya kista yang membahayakan dalam rahim, kanker rahim dan lain sebagainya, maka hal ini diperbolehkan atau bahkan diwajibkan didalam syari'at. Dan jika penggunaan alat kontrasepsi ini dengan alasan karena takut miskin, 
takut tidak dapat membiayai kehidupan keluarga jika anggota keluarga terlalu banyak dan sebagainya, maka hal ini pun juga dihukumi haram secara mutlak. Karena di anggap berprasangka buruk terhadap Allah SWT dan tidak meyakini bahwa Allah SWT yang maha memberi rezeki dan maha kaya.

Sedangkan Tandzimun nasli yang artinya menunda kehamilan hal ini diperbolehkan dalam Agama Islam. Karena hal ini bertujuan untuk pemberian pengaturan jarak kelahiran dan kehamilan yang terlalu dekat dan akan berakibat buruk bagi anak serta ibu. Selain nantinya anak akan kekurangan ASI karena wanita yang sedang hamil produksi ASI berkurang, kondisi sang ibu juga belum pulih betul jika harus sering melahirkan, karena setelah 9 bulan mengandung ibu memerlukan waktu untuk tubuhnya kembali fit. Karena dalam Islam juga di ajarkan bahwasanya wafisoluhu $f i$ 'amain (dan menyusui selama dua tahun penuh). Dan jika semua ini dikiaskan dengan alat lain seperti alat kontrasepsi supaya diatur jarak kelahirannya maka diperbolehkan selagi sifatnya tidak permanen (pemandulan selama-lamanya). Dan perlu diperhatikan juga, untuk pemasangan alat kontrasepsi pada wanita hendaknya dipasangkan oleh suaminya sendiri (jika memang mampu/bisa karena seorang dokter) atau seorang dokter wanita yang solikhah/terhormat karena pemasangan alat kontrasepsi ini akan mengakibatkan tersentuhnya kulit antara satu sama lain oleh karena itu di anjurkan untuk memilih dokter yang sesama jenis agar tidak menimbulkan madzorot.

\section{KESIMPULAN}

Kontrasepsi dilihat dari cara kerjanya ada dua macam yakni kontrasepsi tradisional dan kontrasepsi modern. Kontrasepsi tradisional (tanpa perantara alat teknologi) yang tidak menimbulkan dampak negatif pada kesehatan tubuh penggunanya seperti 'azal, kalender, suhu basal, lendir servik, sympo termal dan lain-lain. Sedangkan alat kontrasepsi modern (menggunakan alat teknologi) yang dapat menimbulkan berbagai macam dampak negatif bagi penggunanya yakni seperti kontrasepsi hormonal, Pil, Suntikan, Susuk KB, AKDR atau IUD, kondom dan kontasepsi mantab atau vasektomi/tubektomi. Pada intinya Semua bentuk alat kontrasepsi ini boleh digunakan dalam Agama Islam. Tentunya dengan tujuan tidak untuk membatasi, mencegah dan mentiadakan kelahiran, kecuali memang benar-benar dalam keadaan dzorurot. Karena jika penggunaan alat kontrasepsi digunakan untuk mentiadakan kelahiran (permanen) jelas jatuh pada hukum yang haram sebab dianggap mendahului takdir atau kehendak Allah SWT dan dalam kondisi seperti ini manusia akan lebih mudah terjerumus dalam perzinaan. Tetapi jika penggunaan alat kontrasepsi tersebut hanya untuk 
mengatur angka kelahiran atau pemberian jarak untuk tidak hamil dan melahirkan terlalu cepat maka dari ijtihad para ulama hal ini diperbolehkan dalam Agama Islam karena memang alat kontrasepsi ini sebagai bentuk pengkiasan cara menunda kelahiran di era globalisasi ini dan diyakini lebih menjamin keberhasilannya khususnya pada alat kontrasepsi modern. Dan jatuh pada hukum haram pula apabila pemasangan alat kontrasepsi ini karena takut tidak bisa membiayai keluarganya karena terlalu banyak anak, khawatir tidak bisa makan, tidak bisa bertahan hidup dan sebagainya, karena dalam posisi seperti ini manusia menganggap bahwa Allah itu tidak menjamin rezeki dalam hidupnya padahal sudah jelas-jelas di terangkan dalam Al-Qur'an dan Sunnah Nabi bahwasannya Allah SWT telah mengatur masing-masing rezeki manusia tinggal manusia tersebut menjemput rezekinya dengan cara berusaha dengan sungguh-sungguh. Hal ini berlaku pula bagi kaum laki-laki, karena pemasangan alat kontrasepsi saat ini sudah banyak sekali bentuk dan macammnya dan bisa dipasang dalam tubuh wanita ataupun pria.

\section{DAFTAR PUSTAKA}

Al-Anshari, Zakaria bin muhammad bin Ahmad bin Zakaria. "Hasyiyatul Jamal 'alal Minhaj Juz 7.” In Hasyiyatul Jamal ’alal Minhaj. Beirut: Darul Kutub 'Ilmiyyah, 2013.

Asqalani, Ahmad bin Ali bi Hajar Al. "Fathul Bari Juz 9." In Fathul Bari. Beirut: Darul Ma'rifat, 1958.

Bakry, Nazar Sidi. “Fikih Dan Ushul Fikih.” Jakarta: PT. Raja Grafindo Persada, 2003.

Handayany, Gemy Nastity. "Kontrasepsi Dalam Kajian Islam.” Jurnal Al-Firk Volume 17 Nomor 1 Tahun 2013, n.d.

Hartanto, Hanafi. "Keluarga Berencana Dan Kontrasepi.” Jakarta: Pustaka Sinar Harapan, 2010.

Joseagush. “Kondom.” WIKIPEDIA, 2019. https://id.m.wikipedia.org.

Manis, Si. “Alat Kontrasepsi.” Pelajaran.co.id, 2019. https://www.pelajaran.co.id.

Nawawi, Imam An. “Al Minhaj Syarah Shahih Muslim Juz 10.” In Al Minhaj Syarah Shahih Muslim. Beirut: Daru Ihyait Turats, 1329.

Qudamah, Ibnu. “Al Mughni Juz 15.” In Al Mughni. Riyadh: Daru Alimil Kutub, 1997. 
Sapiudin, Shidiq. "Fikih Kontemporer.” Jakarta: Kencana, 2017.

Sudrajat, Ajat. "Fikih Aktual Membahas Problematika Hukum Islam Kontemporer." Ponorogo: STAIN Ponorogo Press, 2008.

Sulistio, Erna, and Dwi Ispriyanti. "Penerapan Regresi Logistik Multinomial Pada Pemilihan Alat Kontrasepsi Wanita (Studi Kasus Di Desa Tonggara Kecamatan Kedungbanteng Kabupaten Tegal).” Media Statistika 3, no. 1 (2010): 31-40.

Syatha, Abu Bakar Ustman bin Muhammad. "I'anatut Thalibin Juz 4.” In I'anatut Thalibin. Beirut: Darul Fikr, 2019.

Umairah, Ahmad bin Ahmad bin Salamah Al. "Hasyiyatani Qalyubi Wa Umairah Juz 4." In Hasyiyatani Qalyubi Wa Umairah. Beirut: Darul Kutub Ilmiyyah, 2015.

Zuhaili, Wahbah. "Ushul Al-Fiqh Al-Islami.” Beirut: Dâr Al-Fikr, 1986. 